\title{
BUSINESS AND IT ALIGNMENT
}

\author{
Milosav N. Majstorović \\ Information Technology School, \\ Belgrade, Republic of Serbia, \\ e-mail: milosav.majstorovic@its.edu.rs, \\ ORCID iD: ㄴhttp://orcid.org/0000-0003-0787-7625
}

DOI: 10.5937/vojtehg64-9263

FIELD: Information Technology
ARTICLE TYPE: Review
ARTICLE LANGUAGE: English

Abstract:

Over the last two decades, the need for the alignment of business needs and opportunities of information technology (IT) has been considered one of the key issues in IT management. Research in the field of business and IT alignment gained momentum in the last decade of the last century when it was realized that the costeffectiveness of IT investments directly contributed to the so-called strategic alignment, ie. alignment between business strategy and IT strategy. It is recognized that IT changes the direction in which companies organize their business processes, communication with customers and deliver their products and services.

The aim of this study is to investigate the current situation in solving the problem of business and IT alignment in order to allow a comparison of different definitions and a conceptualization of this phenomenon, and also to consider the efforts made so far in order to solve this problem. The conceptualization of the phenomenon of alignment of business and IT is given through the strategic alignment model that had the biggest impact in this area. The question of the applicability of the model and the framework developed for the purpose of alignment stems from the challenges facing the problem of alignment of business and IT. These challenges are categorized and particularly elaborated in this paper.

Key words: alignment, IT strategy, business strategy, strategic alignment model.

\section{Introduction}

Annual Research Society for Information Management (www.simnet.org) ranked „Business and IT alignment" among the top ten concerns of senior management in the period from 2003 to 2010. Out of 
these 8 years, five years saw it as the „biggest concern" (Silvius, 2013). Despite many studies over several years on the topic of business and IT alignment (the work (Chan, Reich, 2007b) analyzed more than 150 studies on this subject), the fact remains that this topic is at the top of IT and business managers concerns(Silvius, 2013 ).

Alignment in the academic literature is conceptualized in different directions (Chan, Reich, 2007a). One, perhaps the dominant direction, is advocating the principle that IT should be organized and managed in such a way that it reflects business management (Sauer, Yetton, 1997). In (Reich, Benbasat, 1996) alignment is defined as the degree of agreement between the mission, objectives and plans contained in the business strategy with IT strategy. In (Henderson, Venkatraman, 1993) alignment is seen as a level of fit and integration between the business strategy, IT strategy, business infrastructure and IT infrastructure. The authors (McKeen, Smith, 2003) represent the view that strategic alignment exists when the objectives and activities of the organization (the business system) and the supporting information system are in harmony.

In the literature, informal definitions of alignment can also be found. For example, (Campbell, 2005) "Alignment is the joint work of business and IT in achieving a common goal". Similarly, in (Abraham, 2006) "Strategic alignment is when everyone is rowing in the same direction". These perspectives do not refer to the vision, strategy, plans, etc., which are mentioned in many subsequent academic definitions of alignment, but their intuitive meaning is clear. However, due to their lack of precision, these definitions are less helpful in articulating what exactly makes a good alignment and how it can be measured (Chan, Reich, 2007a).

In the literature, in addition to the term alignment, there are also terms such as: fit (Henderson, Venkatraman, 1993), (Wang, 2014), linkage (Reich, 1993) and integration ( Henderson, Venkatraman, 1993). The terms of harmony, bridge and fusion are also used in a similar context and meaning, although there are differences in small details (Chan, Reich, 2007a). In national literature, this area is not specifically addressed regarding this aspect, so this paper adopts the term alignment, starting from the fact that the development of business and IT can be presented and monitored in the vertical plane, and the ultimate goal is that they are at the same level, ie. aligned.

Taking into account the main components of different definitions of the concept of alignment in the literature, (Silvius 2013) gives a wide view of the alignment of business and IT, as well as the extent to which IT applications, infrastructure and organization enable and shape the business strategy and processes, as well as the process, ie. activities or methodologies to achieve a certain degree of alignment.

For studying any complex problem, it is important to do its conceptualization, for example, through the development of appropriate 
models. Models provide a comprehensive and prescriptive approach to the study of the problem of alignment. Since the nineties, many alignment models have been developed, and this paper will focus mainly on the SAM (Strategic Alignment Model) model, which had a great impact in this area (Chan, Reich, 2007a), and served as the basis for many subsequent expansions.

The second chapter of the paper gives an overview of studies related to the problem of alignment of business and IT. The third chapter is dedicated to the conceptualization of the alignment problem. The already mentioned strategic alignment model is presented. The dimensions through which the model describes the alignment of business and IT are defined as well as the fundamental domains of these dimensions and the components of these domains. Some critical reviews of this model are also given, as well as criteria (ie, variables) for measuring the maturity of settling in the Strategic Alignment Maturity Model (Luftman, 2000), which is the most quoted and applied empirical model (Mekawy, et al., 2009). The fourth chapter presents the efforts made to overcome the problem of business and IT alignment and the effects of these efforts. The final chapter gives a conclusion stating the main contributions of this work and possible directions for further research.

\section{Literature review}

Henderson and Venkatraman (Henderson, Venkatraman, 1993) presented a model for the conceptualization and strategic management of information technology (called the Strategic Alignment Model - SAM). The proposed framework is applied broadly and generally considered as a key reference model alignment. The model is defined by four fundamental models. These are: business strategy, information technology strategy, organizational infrastructure and processes, and infrastructure and information technology processes. The interaction of these four components in two dimensions, the integration of strategies and functional integration, form a state space model. From this model, four alignment perspectives are derived with specific implications for management practice (Strategy execution, Technology transformation, Competitive potential and Service level). This context does not present solution artifacts, nor the situational differences of the business and IT alignment problem are considered. The model provides neither constructions for measuring alignment nor the instruments for its achievement. Therefore, empirical studies on alignment generally apply models that can be seen as an extension of the SAM model (Silvius 2013). 
Luftman (Luftman, 2000) developed a tool to measure strategic alignment based on the maturity model which covers six different areas: (1) communication, (2) competence / value, (3) management, (4) partnership, (5) technological environment, and (6) the maturity of skills. This approach enables, to a certain degree, the assessment of the maturity of business and IT alignment in companies. This work was later expanded (Sledgianowski, Luftman, 2005) into the framework of the strategic alignment maturity assessment (SAMA). The assessment tool can be seen as an artifact that supports the solution of the problem, but the approach does not cover the characteristics of different situations in the real world (Saat, et al, 2010).

Chan and Reich (Chan, Reich, 2007a) provide an overview of literature related to the alignment problem in IT. They first discuss the motivation for researching alignment. The dilemma of how much attention should be given to research in this area was highlighted, ie. whether it is always advisable to have strict business and IT alignment. The situations and arguments when strict alignment is not desirable or is generally not possible are given. The authors, however, take the view that alignment is a challenge that deserves attention and study, and that alignment is a value in itself, and that it contributes to the success of the organization. Standing on the view that alignment is neither a static, nor one-dimensional factor or process, being difficult to achieve at the same time, the authors expose many perspectives of alignment and suggest a direction which researchers and practitioners should follow. The definition of alignment is then discussed followed by the presentation of the key alignment dimensions and levels. The following dimensions of alignment are dealt with: strategic / intellectual, structural, informal structural, social and cultural. When it comes to the levels of alignment, the authors point out that it would be ideal to have alignment at all levels of the organization, including the organizational level, the system level, the project level and the individual / cognitive level. The aspects of internal and external alignment are defined and the importance of external alignment is stressed regarding the relations with business partners such as customers and suppliers. The importance of measurement is emphasized and different approaches for assessing alignment are presented. Considering the measurement as granular and descriptive, the authors describe the most significant alignment models, believing that they provide comprehensive and prescriptive approach to the alignment problem. Starting from the fact that alignment can be seen as a construct measured at a given point of time as well as an ongoing process, the authors elaborate the conditions and outcomes of alignment, as well as models of the alignment process. A special value of this detailed alignment literatuture review is a systematization of advice for business managers and IT practitioners. 
The Cuenca at. al. (Cuenca, et. al., 2009) work was based on the thesis that the IT strategy usually depends on the business strategy and that the alignment of the two strategies improves their strategic plans. This paper presents an overview of the strategic alignment between business and IT and proposes the use of EE (enterprise engineering) approach to achieve this alignment. It identifies necessary components for modeling IT strategy and increasing the alignment of business strategy and IT. In accordance with the EE approach, specific building blocks are defined as well as new phases of the life cycle required for incorporating IT strategies into the EA (Enterprise Architecture) framework. These suggestions are illustrated on an example of a company for ceramic tiles.

A business and IT alignment problem analysis done in (Saat, et. Al., 2011), using a prescriptive approach, showed that the alignment of business and IT is not sufficiently specified to allow for a systematic construction of artifacts that would represent a solution to the problem. Also, the existing approaches are not situational and do not reflect the diversity of the alignment problem in the real world. The authors use the decomposition of the target in order to qualitatively characterize the business and IT alignment from the following perspectives: (i) IT system, (ii) business and (iii) IT management. The research study included 174 professionals from different European countries who helped in the identification of four different situations of business and IT alignment. The authors point out that the results of the study can be used to build models and methods that would allow the alignment operationalization as well as its adaptation to the needs of different situations.

Ula and Lai (Ula, Lai, 2011) have presented an objective-oriented framework for the specification of requirements, which takes into account the organizational context, and which should enable that the IT department better understands the business objectives of the organization, so that the IT system can better meet business requirements. The process of managing the procurement of an automobile company is presented as a case study to illustrate the approach.

A framework and a literature review from Aversano et al. (Aversano, et al., 2012) are useful for the evaluation of different approaches to alignment. Referring to the results of some studies that have addressed this issue, they noted that the performance of business and IT is closely linked and that a company cannot be competitive if its business and IT strategy are not aligned.These studies are oriented to different abstract levels, from the functional to the strategic one. Strategic alignment exists when the goals, activities and processes of business organizations are in harmony with the information system that supports them (Croteau, Bergeron, 2001). On the other hand, the functional level of the analysis of alignment between the existing business processes and software systems is necessary to optimize the effectiveness of software support (Aversano, et al., 2012). 


\section{Alignment models}

Models provide a comprehensive and prescriptive approach to the study of the alignment problem. Since the 1990s, many alignment models have been developed; this paper focuses on the SAM (Strategic Alignment Model) model which had a significant impact in this area (Chan, Reich, 2007a) and was the basis for many subsequent expansions.

Initially, IT had a strictly supportive function in business systems and it was the department for assistance. However, with advances in technology, many have realized a new IT potential in executing strategic functions. Strategy is a very interesting and complex discipline. There are different definitions of strategy, depending on the point of view. This paper starts from the following definition: "Strategy is creating a synergy between the company's activities (business system)." Namely, according to (Porter, 1996), if there is no connection between the activities, there is no specific strategy in the company. In such a case, management is reduced to a simpler task of monitoring unrelated functions, and operational effectiveness determines the performance of an organization. Of course, business environment of an organization also plays a significant role in the definition of its strategy.

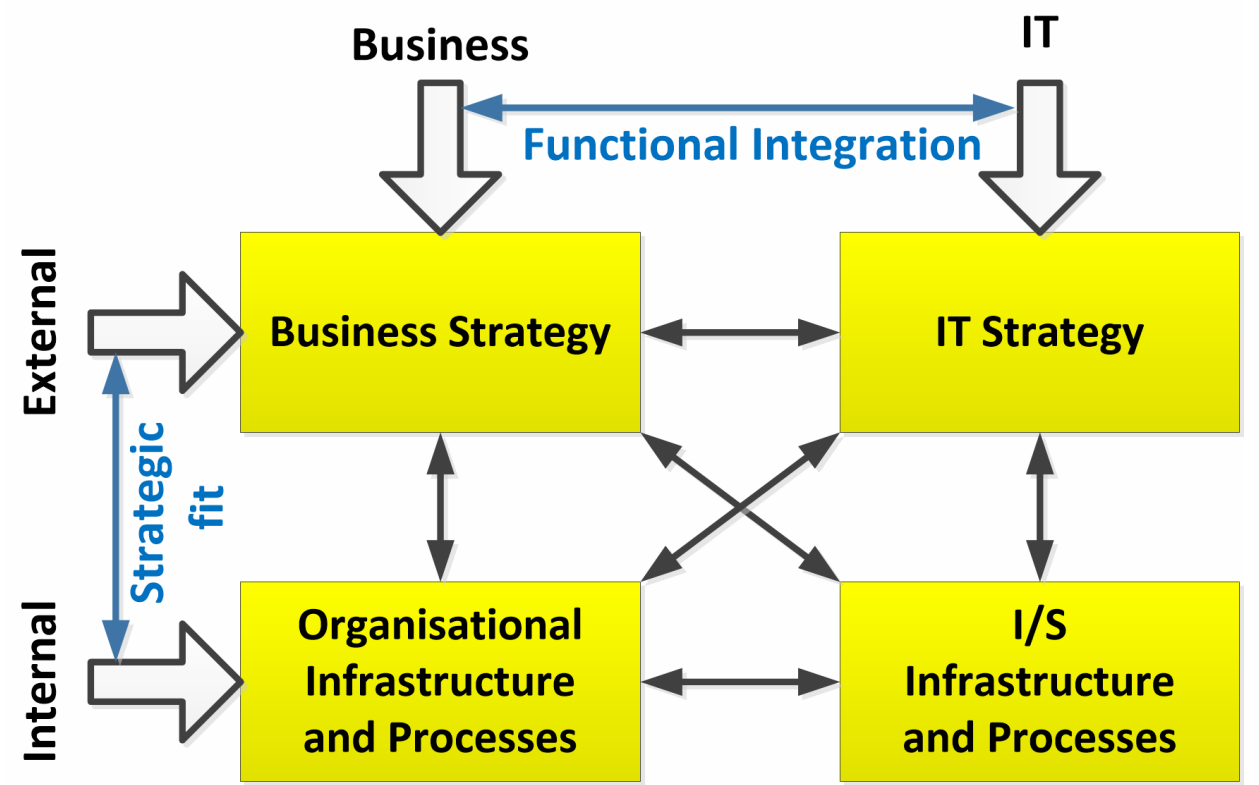

Slika 1 - Strategijski model poravnanja (Silvius, 2007)

Figure 1 - Strategic Alignment Model (Silvius, 2007)

Puc. 1 - Модель стратегического выравнивания (Silvius, 2007) 
The SAM model, defined in (Henderson, Venkatraman, 1993), is a model for the conceptualization and strategic management of information technology. This model describes the alignment of business and IT in two dimensions (Figure 1) (Silvius 2007). The strategic fit differentiates an external focus, aimed at the business environment, and an internal focus, directed towards administrative structures. Thus, the strategic fit represents a vertical link in the SAM model. The second dimension, a functional integration, separates business and IT. Thus, the functional integration represents the horizontal link in the SAM model. Together with these dimensions, the model defines four fundamental domains: business strategy, information technology strategy, organizational infrastructure and processes, as well as infrastructure and information technology processes.

Each domain has its own components. The following is a brief overview of these components (Luftman, 2000).

\section{Business strategy}

The business area comprises the market, products, services, customers / clients and the locations where the company operates, as well as current and potential competition that affect the business environment.

Characteristic competencies: critical success factors and key competencies that provide a competitive advantage to the company. This includes brands (special types of products in the enterprise), research potential, production and product development, cost and price structure of products as well as sales and distribution channels.

Business management: the way the company establishes the relationship between management, shareholders and board of directors. It also includes the impact of legislation on the company and how the company manages connections and alliances with strategic partners.

\section{Organizational infrastructure and processes}

The administrative structure of the organization represents a way to organize a business organization. It may be: centralized, decentralized, matrix, horizontal, vertical, geographic, functional, etc.

Processes are models of business activities (eg. The mode of execution of work by employees). In fact, the main activities are the ones that bring a new value to the organization. An important aspect in this field is the improvement of the process.

Skills are the domain of human resources management, which includes recruitment / dismissal, motivation and training / education of workers. 
The technological scope is the most important software and hardware components.

System competence are special features (eg. access to information that is important for creating / achieving the company's strategy), which are characterized by IT services.

IT management is a way to share the responsibility for resources, risks, conflict resolution in the context of IT, between business partners, IT managers and service providers. Also, project selection and prioritizing for their realization belongs to this component.

\section{IT infrastructure and processes}

Architecture: technological base, the choices and decisions that enable the interaction between software, networks, hardware and management into a cohesive platform.

Processes: actions and activities aimed at the development and maintenance of applications and at managing IT infrastructure.

Skills: Domain of human resources management in IT, which includes hiring / firing, motivation and training / education of workers.

\section{Analysis and criticism of the SAM model}

Although the concept of strategic alignment in the SAM model caused great attention and constituted an important research direction for people from business and IT, both in academia as well as in industrial circles, it has undergone certain criticism (FADE, 2008). Thus, (Ciborro, 1997) points out that the concept of the SAM model does not reflect the reality of the current management practices of real business. The author sees the SAM model as an attempt to merge two extremely unstable variables that represent business and IT strategy. Conceptually, strategic alignment may be well placed, but in everyday business there are significant difficulties in its implementation. Frequent changes in business strategies have resulted in permanent patching of IT support, which results in a shift in the field of IT strategy, ie. its instability. Alignment is a conceptual bridge that makes us appreciate the true nature of the coast that need to be overcome: the management strategy and technology. The strategy seeks to link different things in order to achieve the objective, and the technology embodied in IT infrastructure is prone to constant "detours", since IT is constantly changing, so it is often out of control. Thus, even if the strategic alignment produces some results, they do not last long (Ciborro, 1997). 
Despite the criticism the SAM model experienced, its contribution (and the contribution of models based on its extensions as well) cannot be denied for conceptualizing the problem of business and IT alignment. However, the weakness of this model is reflected in the limited possibilities of application in practice. Therefore, the problem is their operationalization. In order to overcome this problem, there have been developed models and frameworks that represent an empirical elaboration of the alignment problem. The aim of these models is to offer practical tools for measuring the achieved level of alignment. In this context, the most quoted and applied empirical model (Mekawy, et. Al., 2009) is the Strategic Alignment Maturity Model (Luftman, 2000). It defines six criteria (ie, variables) for measuring the alignment maturity. The respective criteria (variables) are listed below together with their brief description.

- Communication. How well the IT and business staff understand each other? Was it easy to make a contact, and how often? Does the company communicate effectively with consultants, vendors, and partners? Is both existing and newly acquired knowledge shared internally, within the organization?

- Value measurement. How well do companies measure their own performance and values of their projects? Are the project strengths and weaknesses assessed on their completion? Are internal processes improved so that the following projects can be better?

- Management. Are the current projects stemming from the understanding of the business strategy? Do they support this strategy? Are IT projects transparent, and is there a responsibility for their outcomes?

- Partnership. Is there a genuine partnership of business and IT, based on mutual trust, sharing risk and success?

- Scope and architecture. To which extent did technology evolve and become something more than just support for business? How and how much did it help business to grow, become more competitive and more profitable?

- Skills. Do staff have the skills necessary to be effective? How well do the technical staff understand the needs of business and speak its own language? How much do the business personnel understand the relevant technology concepts?

\section{Efforts to overcome the business and IT alignment problem and the effects of these efforts}

Silvius (Silvius 2013) performed an analysis of the results achieved in the field of measuring the actual impact of the alignment made in the context of creating a new value. Alignment should contribute to business results from the use of IT, thereby increasing business performance. However, measuring the contribution of IT and investment in IT yields has powered 
intensive research in recent decades. The research results show that the issue is an open problem for IT management and business in general.

Empirical studies have shown different results of the contribution of IT investments to new business values. Several studies have demonstrated the absence of the link between IT investments and the performance of organizations (Silvius 2013). It was concluded that this problem has social and organizational dimensions. Specific IT investments can have positive effects in the organization $A$, but not in the organization $B$, depending on how IT is used. Therefore, IT synergistic effects with other organizational factors must be considered. In addition to the approaches that value the contribution of IT to creating new values in the organization, there are specific approaches that focus on the conditions and situational aspects under which IT creates value in the organization. These approaches are known as procedural approaches to the evaluation of IT (Mooney, et al., 1995). In these approaches the focus is on the issues - why, how and when IT creates value in the organization. The process approach links the value, IT evaluation and alignment. Henderson and Venkatraman (Henderson, Venkatraman, 1993) also suggest that the cost-effectiveness of IT investments is a function of strategic alignment.

\section{Challenges in business and IT alignment}

Despite numerous studies, an apparently "logical" connection between alignment and newly created values of the organization is not sufficiently explored. So, the question remains how alignment affect, or should affect, IT evaluation in the organization. This unexplored connection may be one reason why the alignment of business and IT remains the dominant concern of business and IT menagers. Research by the Society for Information Management (www.simnet.org) showed that, despite the conceptualization and operationalization of alignment, alignment of business and IT remains a challenge for many organizations. This fact raises the question of the applicability of models and frameworks developed for alignment. Silvius (Silvius 2013) analyzed the reasons for this situation. Below is an outline of the main challenges for alignment of business and IT that follow from empirical studies (Silvius 2013).

\section{The problem of the lack of a generally accepted framework or model}

After several years of research in the field of alignment, there is still no recognized, generally accepted framework or model. It should provide a common ground for researchers and practitioners in understanding and study of alignment, in order to acquire further theoretical knowledge and lead to practical applications of this concept. As noted above, the SAM 
model (Henderson, Venkatraman, 1993) can be considered as the starting point for the models and frameworks of alignment of business and IT. Although this model helps in understanding the components that cause alignment, it does not give a way and directions on how to achieve alignment. The models which are an empirical elaboration of the problem of alignment, such as the Strategic Alignment Maturity Model (Luftman, 2000), represent efforts to overcome this problem.

\section{Descriptive and prescriptive models of alignment}

The SAM model as well as the derived models representing a conceptual elaboration of the alignment problem are mainly descriptive by their nature. These models provide a view or perspective of what alignment is, i.e. they define the different components that contribute to alignment. Their application in practice requires "translating" from the descriptive theory to the prescriptive theory. The term prescriptive here refers to a way of providing a roadmap or guidance on how to achieve alignment (Silvius 2013). The implementation of alignment models in organizations requires more detailed interpretations and definitions than those already available, for example the SAM model. The maturity model for strategic alignment (Luftman, 2000) provides a more prescriptive approach. However, its implementation requires taking into account a specific organizational context.

\section{Limited ability to measure alignment}

For anyone interested in the management of alignment in the organization, it is important to have a clear picture of what alignment is and how it is assessed. This follows from the proven truth that we cannot change something we cannot manage, and one cannot manage something that cannot be measured. An important condition for improving alignment of business and IT is the availability of tools for measuring alignment. The models listed indicate the components that contribute to alignment. However, there is no agreement about how these components can be assessed in a concrete alignment analysis (Silvius 2013).

\section{Alignment requires a comprehensive approach}

Another reason why alignment is hard to attain is that professionals often look for a simple solution to achieve this goal. In different moments and situations, this "magical solution" is expected from the framework for processes (such as eg. ITIL and COBIT), from IT architecture or, for example, from IT management. The conceptualization and operationalization of alignment discussed above require, however, a comprehensive approach in which there are very few easy solutions (Silvius 2013). 
The problem of lack of knowledge and weak definitions of business

Alignment is not possible if the business strategy is not known or is in the process of creating (Chan, Reich, 2007a). Most alignment models start from the identification of the business strategy as one of the organizational components with which alignment should be performed. An unknown business strategy, or if the business strategy is unclear, represents the logical challenge for the alignment of business and IT. Thus, the lack of a business strategy or its vague definition can keep the problem of business and IT alignment at its beginning.

Dynamic reality

Practical problems of business and IT alignment stem from an increase in dynamics and volatility of markets and organizations. Organizations are trying constantly to adapt to changes in the market, technology, customer requirements, etc. Since this is a continuous process of change, in (Chan, Reich, 2007a) it is noted that: „there is no such a thing as a 'state' of alignment". In such environment and context, alignment of business and IT can never be reached. Several authors emphasized that alignment is a process rather than a 'state' (Silvius 2013). With this in mind, organizations need to continuously and adequately manage the process of alignment of business and IT.

\section{Evolutionary role of IT}

A particular reason for the disconnection between theory and practice of alignment can be found in the altered role of IT in organizations. Many studies were conducted on alignment 10 to 20 years ago. However, in the last decade there has been a change in the role of IT in organizations. For example, the Internet enables organizations to create new outlets for their products or services, to develop new services that affect retention and loyalty of the existing ones, as well as to acquire new customers. In short, IT is changing business organizations, and from a factor that enables business, which is a traditional view of IT, it becomes an instrument that develops and improves operations. Since IT is increasingly integrated into products, services and market organizations, its changed role has resulted in an increased impact on achieving alignment. Alignment means no more how much IT is aligned with business, but how much business is aligned with IT (Luftman, Kempaiah 2007). 


\section{Conclusion}

For a long time, business and IT alignment has been attracting the attention of both academic communities and companies that want to become and stay competitive in the market competition. The performances of business and IT are closely linked, and companies cannot be competitive if their business and IT strategies are not aligned, ie. coordinated. The aim of this study is to determine as precisely as possible the phenomenon of conceptual alignment, make its conceptualization and define the problems and challenges that stand in the way of successful implementation of business and IT alignment.

In order to fulfill this objective, the author has reviewed extensive contemporary and relevant literature related to the problem of alignment. The analysis of research in this area has led to the conclusion that there is no single definition of the concept of alignment. In addition to the formal, substantiated corresponding models, there are informal definitions, which are intuitive and help to understand this phenomenon, but are less helpful in articulating what exactly makes good alignment and how it can be measured.

In addition to the precise definition of the term alignment, this paper gives different approaches to the conceptualization of this problem through the presentation of the most significant models of alignment. In fact, the greatest attention was paid to the strategic alignment model that had a great impact in this area (Chan, Reich, 2007a) and was the basis for many subsequent expansions.

The special contribution of this work is the systematization of efforts made in solving the problems of business and IT alignment. We analyzed the results achieved in this field, and identified the problems and challenges that stand in the way. The identified problems and challenges are the motivation for further work of the author in this domain. In order to seek solutions that will alleviate the problem of alignment of business and IT, and that will enable this alignment to be realized to a greater extent, the following approaches are to be researched and applied:

- enterprise architecture as a way of a comprehensive and unified modeling of an organization, its business and IT,

- formal modeling of the business processes of the organization and their execution, analysis, monitoring and upgrading using the system for business process management.

As expected, these approaches should enable the continuous management of the problem of alignment of business and IT. Krstajic et. al. (Krstajic, et. al., 2014) used an approach based on enterprise architecture (EA) as a direction of the alignment of business and IT in the field of insurance industry. Given the growing importance of service- 
oriented business, the results of the planned research could be used to create a specific methodological framework for the development of EA in the field of service-oriented business and for contributing to its operationalization through the definition and implementation of software tools for business process management.

\section{Literature / References}

Abraham, G.A.(2006). Successful Organizational Leadership: Effective execution through strategic management. Preuzeto sa http://www.refresher.com/Archives/agaaexecution.html 2015 Jul 25.

Aversano, L., Grasso, C., \& Tortorella, M. 2012. A literature review of Business/IT Alignment Strategies. Procedia Technology, 5, str.462-474.

Campbell, B. 2005. Alignment: Resolving ambiguity within bounded choices. . U: PACIS, Bangkok, Thailand. , str.1-14

Chan, Y.E., \& Reich, B.H. 2007a. IT alignment: What have we learned. Journal of Information Technology, 22(4), str.297-315. doi:10.1057/palgrave.jit.2000109

Chan, Y.E., \& Reich, B.H. 2007b. IT alignment: An annotated bibliography. Journal of Information Technology, 22(4), str.316-396. doi:10.1057/palgrave.jit.2000111

Ciborra, C.U. 1997. De Profundis?, Deconstructing the concept of strategic alignment. Scandinavian Journal of Information Systems, 9(1), str.67-82.

Croteau, A.M., \& Bergeron, F. 2001. An information technology trilogy: Business Strategy, technological deployment and organizational performance. Journal of Strategic Information Systems, 10(2), str.77-99.

Cuenca, L., Boza, A., \& Ortiz, A. 2011. An enterprise engineering approach for the alignment of business and information technology strategy. International Journal of Computer Integrated Manufacturing, 24(11), str.974-992.

Fadeel, R.S. 2008. Business-IT Strategic Alignment Concept in Theory and Practice.University of Göterborg.

Henderson, J.C., \& Venkatraman, N. 1993. Strategic alignment: Leveraging information technology for transforming organizations. IBM Systems Journal, 32(1), str.4-16.

Krstajić, D., Cvetković, R., \& Majstorović, M. 2014. Towards the alignment of business and IT in insurance company. International Journal of Scientific and Research Publications, 4(3), str.1-7.

Luftman, J.N. 2000. Assessing Business-IT Alignment Maturity. Communications of the Association for Information Systems (AIS), 4(14), str.1-50.

Luftman, J., \& Kempaiah, R. 2007. An Update on Business-IT Alignment: A Line Has Been Drawn. MIS Quarterly Executive, 6(3), str.165-177.

Mckeen, J.D., \& Smith, H. 2003. Making IT Happen: Critical issues in IT management. Hoboken NJ: Wiley.

Mekawy, M., El Rusu, L., \& Ahmed, N. 2009. Business and IT Alignment: An Evaluation of Strategic Alignment Models. Communications in Computer and Information Science, 49(3), str.447-455.

Mooney, J., Gurbaxani, V., \& Kraemer, K. 1995. A process oriented framework for assessing the business value of information technology... U: Sixteenth Annual International Conference on Information Systems (ICIS), Amsterdam. , str.17-27

Porter, M.E. 1996. What is strategy?. Harvard Business Review, 74(6), str.61-78. 
Reich, B.H. 1993. Investigating the Linkage between Business and Information Technology Objectives: A multiple case study in the insurance industry, PhdThesis University of British Columbia.

Reich, B.H., \& Benbasat, I. 1996. Measuring the Linkage between Business and Information Technology Objectives. MIS Quarterly, 20(1). 20(1): 55. doi:10.2307/249542

Saat, J., Franke, U., Lagerström, R., \& Ekstedt, M. 2010. Enterprise Architecture Meta Models for IT/Business Alignment Situations. . U: 14th IEEE International Enterprise Distributed Object Computing Conference, Vitoria. , str.14-23

Saat, J., Winter, R., Franke, U., Lagerstrom, R., \& Ekstedt, M. 2011. Analysis of IT/Business Alignment Situations as a Precondition for the Design and Engineering of Situated IT/Business Alignment Solutions. . U: 44th Hawaii International Conference on System Sciences, Hawaii, USA. , str.1-9

Sauer, C., \& Yetton, P.W. 1997. The Right Stuff - An introduction to new thinking about management. U C. Sauer\& P.W. Yetton Ur., Steps to the Future: Fresh thinking on the management of IT-based organizational transformation, 1st.San Francisco: JosseyBass., str.1-21.

Silvius, A.J.G.(2007). Business \& IT Alignment in theory and practice. Preuzeto sa http://www.computer.org/csdl/proceedings/hicss/2007/2755/00/27550211b.pdf 2015 Jul 1.

Silvius, A.J.G. 2013. Business and IT aligment in context.Utrecht: Utrecht University.

Sledgianowski, D.J.N., \& Luftman, J.N. 2005. IT-Business Strategic Alignment Maturity: A Case Study. Journal of Cases on Information Technology, 7(2), str.102-120.

Ula, A., \& Lai, R. 2011. Modeling Business Goal for Business/it Alignment Using Requirements Engineering. Journal of Computer Information Systems, 51(3), str.21-28.

Wang, Z. 2014. Strategic Fit Issues in Information System Research: Concept, Operationalization and Future Directions. International Journal of Hybrid Information Technology, 7(1), str.13-24.

\section{ВЫРАВНИВАНИЕ БИЗНЕСА И ИНФОРМАЦИОННЫЕ ТЕХНОЛОГИИ}

Милосав Н. Майсторович

Колледж информационных технологий, Белград, Республика Сербия

ОБЛАСТЬ: информационные технологии

ВИД СТАТЬИ: обзорная статья

ЯЗЫК СТАТЬИ: английский

\section{Резюме:}

Более двух десятилетий необходимость выравнивания потребностей бизнеса и возможностей информационных технологий (ИТ) рассматривается, как один из ключевых вопросов в области управления ИТ. Исследования в области выравнивания бизнеса и ИТ стали расширятся за последнее десятилетие прошлого века, когда стало ясно, что экономическая эфрфективность инвестиций в ИТ непосредственно участвует в, так называемой, стратегической ориентации, заключающейся в выравнивании ме- 
жду бизнес-стратегией и ИТ-стратегией. Стало очевидным, что ИТ направления меняются, в связи с чем компании стали сами осуществлять собственные бизнес-процессы, коммуникацию с клиентами, поставку продукции и предоставление услуг.

Целью данного исследования является изучение текущей ситуации в решении проблем выравнивания бизнеса и ИТ, сопоставительный анализ различных определений и концептуализации этого явления, а также анализ применяемых методов при решении данных проблем.

Концептуализация выравнивания бизнеса и ИТ осуществляется через модель стратегического выравнивания, которая является важнейшим фактором в этой области. В статье приведены и проанализированы разработанные модели и методы, применяемые в области выравнивания бизнеса и ИТ.

Ключевые слова: выравнивание, ИТ-стратегии, бизнес стратегии, модель стратегического выравнивания.

\section{PORAVNANJE POSLOVANJA I INFORMACIONE TEHNOLOGIJE}

Milosav N. Majstorović

Visoka škola strukovnih studija za informacione tehnologije,

Beograd, Republika Srbija

OBLAST: informatika

VRSTA ČLANKA: pregledni članak

JEZIK ČLANKA: engleski

Više od dve decenije neophodnost poravnanja poslovnih potreba $i$ mogućnosti informacione tehnologije (IT) razmatra se kao jedno od ključnih pitanja u upravljanju IT-om. Istraživanja u oblasti poravnanja poslovanja i IT dobijaju na zamahu u poslednjoj deceniji prošlog veka, kada se uvidelo da je isplativost ulaganja u IT u direktnoj funkciji tzv. strategijskog poravnanja, tj. poravnanja između strategije poslovanja i strategije IT-a. Uvidelo se da IT menja pravac u kojem kompanije organizuju njihove poslovne procese, komunikaciju sa kupcima $i$ isporuku svojih proizvoda $i$ servisa.

Cilj ovog rada je istraživanje trenutnog stanja u rešavanju problema poravnanja poslovanja i IT, kako bi se poredile različite definicije, i predstavila konceptualizacija ovog fenomena, kao i sagledavanje napora koji se čine radi rešavanja ovog problema. Konceptualizacija fenomena poravnanja poslovanja i IT predstavljena je kroz strategijski model poravnanja koji je imao najveći uticaj na ovu oblast. Pitanje primenljivosti modela i okvira razvijenih radi poravnanja sledi iz izazova koji stoje pred problemom poravnanja poslovanja i IT. Ovi izazovi su kategorisani i posebno elaborirani u radu.

Ključne reči: poravnanje, IT strategija, poslovna strategija, strategijski model poravnanja. 
Paper received on / Дата получения работы / Datum prijema članka: 12. 10. 2015. Manuscript corrections submitted on / Дата получения исправленной версии работы / Datum dostavljanja ispravki rukopisa: 03. 11. 2015.

Paper accepted for publishing on / Дата окончательного согласования работы / Datum konačnog prihvatanja članka za objavljivanje: 05. 11. 2015.

(c) 2016 The Author. Published by Vojnotehnički glasnik / Military Technical Courier (www.vtg.mod.gov.rs, втг.мо.упр.срб). This article is an open access article distributed under the terms and conditions of the Creative Commons Attribution license (http://creativecommons.org/licenses/by/3.0/rs/)

(c) 2016 Автор. Опубликовано в "Военно-технический вестник / Vojnotehnički glasnik / Military Technical Courier" (www.vtg.mod.gov.rs, втг.мо.упр.срб). Данная статья в открытом доступе и распространяется в соответствии с лицензией "Creative Commons" (http://creativecommons.org/licenses/by/3.0/rs/).

(c) 2016 Autor. Objavio Vojnotehnički glasnik / Military Technical Courier (www.vtg.mod.gov.rs втг.мо.упр.срб). Ovo je članak otvorenog pristupa i distribuira se u skladu sa Creative Commons licencom (http://creativecommons.org/licenses/by/3.0/rs/). 